\title{
Analysis and Enlightenment of Teaching Characteristics of the Applied Technology-Oriented Universities in the UK
}

\author{
Feng-hua $\mathrm{XU}^{*}$ \\ School of Sciences, Hubei University of Automotive \\ Technology, Shiyan, Hubei, 442002, China \\ *fenghua_xu@163.com \\ Wen-han ZENG \\ Centre for Precision Technologies, University of \\ Huddersfield, Huddersfield, HD1 3DH, UK \\ wenhanz@hotmail.com
}

\author{
Sheng-huai WANG \\ School of Mechanical Engineering, Hubei University of \\ Automotive Technology, Shiyan, Hubei, 442002, China \\ shwangkb@163.com \\ Tu-kun LI \\ Centre for Precision Technologies, University of \\ Huddersfield, Huddersfield, HD1 3DH, UK \\ tukunli@gmail.com
}

\begin{abstract}
Aiming at the transformation and development trend of local colleges and universities in China, this paper takes the University of Huddersfield as an example to study the undergraduate education of applied technology-oriented universities in the UK. And it analyzes the teaching guiding ideology, teaching theory, educational idea and orientation, professional standards and certifications, curriculum and evaluation, student internships and employment, teaching and scientific research of teachers. All of these provide valuable reference for the transformation and development of local colleges and universities in China.
\end{abstract}

Keywords-applied technology-oriented; undergraduate education; transformation and development; the United Kingdom; learning paradigm

\section{INTRODUCTION}

Local colleges and universities have become the main force of popularization of higher education in China at present, but some local colleges and universities are in the predicament of development, especially the newly built universities and independent colleges are more prominent, so the Chinese Ministry of Education puts forward to the transitional development of Colleges and Universities from regular undergraduate institutions to applied technology-oriented universities. The transformation is not just the adjustment of professional, teaching plan and curriculum, the key adjustment is the goal of education which should be demand-oriented, it needs a comprehensive security reform of the training model, faculty structure, cooperation route of the school, evaluation of the quality of education and guarantee for teaching conditions [1]. The University of Huddersfield upgraded to applied technology-oriented university after 1992.This University not only provides high quality teaching, but also combines with high academic standards of the internship experience, and enhances the competitiveness of graduates in the labor market [2]. This paper takes the undergraduate teaching of this school as the research object, analysis of the teaching mode and characteristics of the University in the UK, in order to provide a reference for the transformation and development of local colleges and universities in China.

\section{STUDENT-CENTERED EDUCATION GUIDELINES}

The British government issued a White Paper on higher education in 2011. This White Paper focuses on higher education funding, university information disclosure, teaching innovation, enrollment reform, educational equity, management framework and other content. It provides a better learning experience for students and ensures the quality of graduates and promotes the development of higher education institutions [3-4]. It promotes the marketing of higher education and puts forward the idea of "student-centered". The white paper is divided into six parts, there are two major parts directly related to the teaching of the students. Among them, the second part is the publicity of university information, which requires the university to provide the students with sufficient information. The information includes such as teaching time, the cost of accommodation, graduate employment rate and starting salary, arrangement of teaching resources, teaching effect, teaching quality and so on. Among them, the curriculum evaluation and detailed rules of college tuition, the professional qualifications of the school, and the resource of students have direct contact with the teaching quality and professional quality of the staff of higher education institutions. At the same time, it also increases competition among institutions of higher education. The information announced will be shared by the Statistical Commission of Higher Education, Higher Education Funding Council for England, the British Federation of Students and the relevant institutions. By comparison and identification of the data provided by the official institutions, students can make a better choice. The third part, which is related to the student's teaching, is the quality of the graduates. This part suggests that a better learning experience should be provided 
to students, so that students can become more qualified graduates.

Higher education institutions attach great importance to the quality of education in the UK, the government guarantees the quality through the higher education policy. Then the higher education can not only respond to the social demand, but also keep the self - individuality of higher education. And the organizations which include British student survey organization, college quality assurance advisory committee, the England high education funding council, the office of independent judges, the institute of higher education can provide feedbacks on the development of the students. These organizations are based on the choice of students, they urge the higher education institutions to play their role in education, guarantee the teaching quality, strengthen the service to the students and the welfare requirement, cultivate the students' ability to obtain employment, establish cooperation with the Business Companies, and promote the efficiency of innovation. The white paper clearly requires all colleges and universities to do a good job at teacher training, to help new teachers to improve teaching ability, so that students can get a better education.

The student-centered educational guiding ideology has been fully reflected in the University of Huddersfield. When you visit the school website, you will see the information which include the annual report of the school, financial statements, staff information and evaluation of various evaluation agencies such as employment rate, student satisfaction survey, employer satisfaction survey, investigation on the degree of the satisfaction of staff to school. The research excellence assessment of the whole British university, etc. Visitors can not only understand the overall operation of the school, teachers and other comprehensive information, but also understand the situation of the school in the same industry. According to this information, the staff of the school can improve the work better. In view of the teacher training, the school will publish its annual plan to the internet at the beginning of each new school year, the annual plan includes specific content, time, location, etc. Training content is very extensive, it includes all aspects of teaching and development of teachers. And the teaching committee, the curriculum committee, the module committee, the test team and the corresponding industry certification standards are used to ensure the quality of students.

\section{TEACHING THEORY BASED ON LEARNING PARADIGM}

The paradigm shift theory of university education was put forward by the American education expert B. Barr Robert and Tagg John in the ninety's of last century [5] . They put the "student-centered and learning-centered" education thought highly condensed and put forward a new paradigm of University Education -"Learning Paradigm". They argued that the traditional 'instruction paradigm' took the University as a teaching institution that provides knowledge, but the new paradigm shift was intended to build the university into a mechanism for learning. Learning paradigm regarded the University as an organized and systematic study environment, and the University can use the experience to promote students to take the initiative to find and construct their own knowledge, to enable students to become the learners who can find the problem and solve the problem, and thus the University can provide more abundant resources and a better learning environment for learners.

Transformation from "teaching paradigm" to "learning paradigm" summarizes the core ideas of the reform of the university education and promotes the popularization of the concept of education, such as the student centered and the learning-centered. The "learning paradigm" requires the university to be built into a learning organization, teachers, administrators, students, and even dorm staffs are learners of learning community, they work together to create a rich environment to promote the student's deep learning and significant learning. The ultimate goal of learning paradigm is to promote students' learning, and to ensure and improve the teaching quality of University.

The University of Huddersfield has been fully reflected the teaching theory based on learning paradigm. At the school level, the school's support for students is reflected in three aspects: (1)School provides students with professional consulting services which include disability, spiritual care and church pastor, accommodation, finance and occupation, etc. (2) the school provides students with learning center services which include libraries and computer equipment, initial enrollment guidance and continuing academic support. (3) the school provides support services which include the language training of overseas students and helping overseas students to integrate into the British culture more quickly. At the Academy level, each college provides a detailed training plan according to the student's major, the detail is the following: (1) they provide students with professional admission guidance. (2) they provide the students with a personal tutor, students can discuss their personal and academic problems with their tutors, and make their own personal development plan under the guidance of the tutor. (3) the students are equipped with grade homeroom teachers who guide they in their academic progress. (4) the students are equipped with the course tutor who guide students to solve academic problems. (5) they contact the students who have low attendance and provide the necessary advice for them. (6) they provide students with all kinds of supporting documents in the form of online or print, the supporting documents include the student handbook, curriculum manuals, training programs, etc. All courses and grades are found in the school's virtual learning environment (UniLearn). In the curriculum, all kinds of information which related to the course can be found on the UniLearn. The whole study takes the student as the center. School, colleges and curriculum teachers create a learning environment for students from different levels.

\section{THE IDEA AND TEACHING MEASURES OF RUNNING A SCHOOL BASED ON APPLICATION TECHNOLOGY}

\section{A. The Concept and Orientation of Running a School}

The history of the University of Huddersfield can be traced back to the institute of science and machinery of Huddersfield which founded in 1825, the institute became a mechanical training school in 1844, and it was upgraded to a comprehensive university until 1992. With the advent of the 
era of knowledge economy, the school puts "focus on knowledge exchange activities, promote distinguished teaching and research" as a long-term goal. The school aims to become an internationally renowned incentive and innovative university, it provides students with opportunities to challenge and create excellent career development; it also provides students with a high quality learning environment.

\section{B. Professional Standards and Certifications}

The professional specification information of the universities of British is very clear and detailed. It includes the professional degree granting institutions, teaching institutions, teaching faculties, course certification organization, educational systems, conferment of academic degrees, professional name, college entrance application office code, the statement of basic disciplines, professional specifications date, the professional course teaching objectives, expected learning outcomes, curriculum module structure and the credit requirements, teaching and evaluation requirements, support for students and their learning, admission standards, evaluation and methods to improve the teaching quality and standard, the annual rules for academic evaluation and quality and standard indicators and so on [6].

Because the school puts training the professional personnel with strong ability of employment as the goal, the professional certification recognized by the industry is very important. In mechanical engineering, for example, the British Institution of Mechanical Engineers (referred to as IMechE) authenticate the profession according to the UK Standard for Professional Engineering Competence (referred to as UK-SPEC). IMechE has more than 150 years of history, it is the first set of mechanical engineering academic groups, and it is recognized by the global mechanical engineering practitioners. UK-SPEC sets up the ability and commitment requirements for registered engineering and technical personnel, sub engineers and licensed engineers.UK-SPEC is a regulatory body for the UK engineering industry, it is responsible for setting and maintaining internationally recognized standards of professional competence and commitment. At the same time, the professional specifications are vetted by the British Higher Education Quality Assurance Agency (QAA), so as to form the industry academic institutions, education management agencies and industry regulatory bodies, and other multidimensional guarantee system of the cultivation of students' professional ability.

Students in other majors of the school, were also authenticated by the standard of trade associations and professional skill and audited by education management institution, so as to ensure the graduates with a high employment rate and the graduates can be recognized by the industry.

\section{Curriculum and Evaluation}

The curriculum is based on the professional standard, and the model is set up in the form of the module. Take the case of Mechanical Engineering, the length of schooling of the major is three years, students are required to complete the module which includes the project communication and materials, manufacturing technology and workshop assessment, professional learning and computer information technology, mechanical engineering science, mathematics, mechanical and electrical systems, thermodynamics, power systems and so on. The design of each module includes the module code, name, teaching institutions, applicable major, person in charge, type, credit, level of ability, teaching methods, prerequisite condition, preview content, sharing teaching, professional requirements, whether classification, whether exclusion combination, etc. In the teaching mode, the teaching theory of learning paradigm is embodied, the proportion of classroom teaching hours is generally small in the total class hours, and the proportion of student centered learning is larger.

In learning achievement, students need to be reflected in two aspects: knowledge and understanding, skills. It is necessary to master the basic principles and methods of professional field, but also needs to master relevant technical skills. In assessing strategy, it includes formative assessment and summative assessment.

Formative assessment is a developmental evaluation based on the continuous observation, record and reflection of the whole process of students' learning, the purpose is to encourage students to learn, to help students to effectively control their own learning process, then the students can get a sense of accomplishment, advance their confidence, and cultivate the spirit of cooperation, then the students can become the main part and the active participants of the assessment.

Summative assessment takes the test result as the final judgment standard, this is no doubt in a way to strengthen the role of scores, and students are more passive to accept this kind of evaluation. Since summative assessment is easier to guarantee in terms of fairness and impartiality than formative assessment, so usually summative assessment and formative assessment are combined together according to the content of the module, and each has a strong bias.

\section{Student Internships and Employment}

The University of Huddersfield not only provides highquality teaching but also highlights the characteristics of the industry. The sandwich courses with high academic standards are presented to enable students to gain a period of practical experience and enhance their competitiveness in the graduation labor market. Take the case of undergraduate course of three years of schooling, students can choose to study in school for two years, the third year, students go to the industry enterprises to practice, and then they return to school to finish the final year of study, the course is called "sandwich course ". The school is one of the five best universities to offer sandwich courses in the UK. After a period of paid work experience, Students can integrate into the study better; they have an obvious advantage to find a job after graduation.

In the service of local industries, the school provides courses closely combined with the needs of local business. Take the mechanical engineering major as an example, West Yorkshire has 50 years of history in the manufacturing of exhaust gas driven turbocharger. With the rapid growth of this industry in the region, the relevant knowledge and skills 
reserves have been formed; the region has maintained the leading level of the world in the relevant technical aspects.

The school offers related courses and provides practical platforms for the students. So that the graduates can enter the Cummins turbo technology company, Bentley Motors Limited, General Motors and British Aerospace and other international enterprises to engage in design, manufacturing, management and sales work. In addition, the school employment service center provides students with a comprehensive employment support which includes resume production, interview training, career choice, skills assessment, psychological testing and other aspects of employment related. All support is used to help students to improve their employability.

\section{E. Teaching and Scientific Research of Teachers}

The University of Huddersfield attaches great importance to teaching work. According to the provisions of the British Higher Education, they implement strict examination of the teacher's teaching ability, all the teachers certified by the industry, these ensure that students can receive high-quality teaching.

Although the total amount of the research of the school is smaller than the most competitive universities in the UK, scientific research of the school is dominated by cutting-edge application technology, and they maintain a deep cooperation with international famous enterprises in the industry, then teachers master the leading technology, they can guide students to contact the professional front knowledge in the teaching process, and enhance the employability of students.

In 2014, the scientific research assessment activities of British universities and research institutions showed that the scientific research results of the school are $15 \%$ for the international leading level, $44 \%$ for the international advanced level, most of them have a good application prospects.

With its precision technology research center as an example, the center is the best research center in the UK; the center is also the EPSRC centre for Innovative Manufacturing in Advanced Metrology. The center not only undertakes a large number of research projects in EU and UK, but also maintains a deep cooperation with international famous enterprises in research and development, it ensures that the center has a leading edge in precision measurement technology innovation. These not only promote the rapid transformation of knowledge to productivity, but also provide a good platform for undergraduate teaching.

\section{THE CONCLUSION}

The University of Huddersfield has always insisted on the concept and orientation of running the school with students' employment, the school adheres to the student centered educational guiding ideology and teaching theory based on learning paradigm. It provides teaching support from many dimensions such as professional certification, curriculum evaluation, student employment and teacher's teaching and scientific research, it provides education, training and research facilities in a wide range of services, and serves the community, so that the school has become a popular and innovative international modern university. There are many that we can learn from. According to the trend of the transformation and development of China's general undergraduate colleges and the requirements of the national strategic planning of "China manufacturing 2025", local colleges and universities should closely cooperate with industry enterprises and local industries, and colleges and universities should establish a practical teaching system with its own characteristics, they should do a good job in the construction of professional teachers and cultivate the talents with its own characteristics. Then it can play an important role in promoting the employment of students and the development of the school, it can also improve the ability of technological innovation and optimize the local industrial structure.

\section{ACKNOWLEDGMENT}

This project is funded by the National Natural Science Foundation of China (No.51275159, 51475150), the Scholarship under the State Scholarship Fund of China (No. 201308420014), the Natural Science Foundation project of Hubei Province of China (No.2013CFB045), the Higher Education Research Project of Education Hubei Province of China (No.2014329), and the Twelfth Five-Year Plan project for Education Science of Hubei Province of China (No. 2014B188).

\section{REFERENCES}

[1] Zhong jiang Wu, Cheng liang Huang. The Connotation of Applied Talents and Cultivation of Application-oriented Graduates [J]. Study of Higher Engineering Education, 2014(2) : 66-70.(In Chinese)

[2] Cai ping Du. The School Orientation and Talent Training of Polytechnic Colleges in the United Kingdom[J]. Research of Higher Education, 2011(12) : 104-109. (In Chinese)

[3] Department for BIS UK. Higher Education: Students at the Heart of the System[R]. Cm 8122, 2011: 1-79.

[4] Ke Ying, Bin Yu. Higher Education: Student-Centered-Review of the white paper on Higher Education in the United Kingdom in 2011 [J]. Journal of Jimei University, 2014(4) : 41-45. (In Chinese)

[5] Robert B. Barr, John Tagg. From Reaching to Learning-A New Paradigm for Undergraduate Education [J]. Change, 1995.27(6) : 12-25.

[6] University of Huddersfield. Programme Specification-Mechanical Engineering [EB/OL]. (2014-01) [2016-09-16].http:// www.hud.ac.uk/courses. 